Available online on 15.07.2015 at http://jddtonline.info

Journal of Drug Delivery and Therapeutics

Open access to Pharmaceutical and Medical research

(C) 2015, publisher and licensee JDDT, This is an Open Access article which permits unrestricted noncommercial use, provided the original work is properly cited

RESEARCHARTICLE

\title{
A COMPARATIVE STUDY OF THE EFFECT OF MOXONIDINE AND TELMISARTAN ON BLOOD PRESSURE AND INSULIN RESISTANCE IN HYPERTENSIVE PATIENTS
}

\author{
* Rajan ${ }^{1}$, Rai Jaswant ${ }^{2}$, Sandhu P S ${ }^{3}$ \\ ${ }^{1}$ Senior Resident, Deptt. of Pharmacology, PGIMER, Chandigarh-India \\ ${ }^{2}$ Professor And Head, Deptt. of Pharmacology, Govt. Medical College, Amritsar- India \\ ${ }^{3}$ Professor, Deptt. of Medicine, Govt. Medical College, Amritsar- India \\ *Corresponding Author's Email: rkhandotra@gmail.com
}

Received 16 May 2015; Review Completed 03 June 2015; Accepted 08 June 2015, Available online 15 July 2015

\begin{abstract}
:
Background: Hypertension being a major cause of cardiovascular diseases worldwide is associated with the overactivation of Renin Angiotensin System (RAS). Both hypertension and insulin resistance are important components of metabolic syndrome and a strong association exists between these two. Some of Previous studies conducted on Moxonidine and Telmisartan suggest, these agents have a better efficacy and safety profile than other antihypertensives The present study is an effort to focus on the effectiveness of these drugs on hypertensive people of Majha region of Punjab, India.

Aim: To compare the effects of both drugs as monotherapy on the various parameters of blood pressure, insulin resistance and lipid profile.

Material and Methods: It was a randomized (1:1), open label, parallel, comparative study. Moxonidine $0.3 \mathrm{mg}$ in one group (A) $(n=30)$ and telmisartan $40 \mathrm{mg}$ in other group (B) $(n=30)$ were used daily for 12 weeks in hypertensive patients. Patients were evaluated at day 0 and at 12 weeks.

Results: Fall in SBP levels by $9.5 \%$ in group-A and $7.4 \%$ in group-B $(\mathrm{p}<0.0001)$ was observed while DBP levels decreased by $8.9 \%(\mathrm{p}<0.0001)$ in group A and by $5.6 \%(\mathrm{p}<0.01)$ in group B. HOMA-IR value was drop by $7.0 \%$ and $7.2 \%$ in group A and B respectively. A mean fall of $8 \%$ in TC levels $(\mathrm{p}<0.0001)$ and a mean fall of $10 \%$ in LDL-C levels was observed in group B. In group $\mathrm{A}$, reduction of $12.5 \%$ ( $<<0.0001)$ in TG levels was observed. BP goal to achieve $\mathrm{SBP}<140 \mathrm{~mm} \mathrm{Hg}$ and DBP $<90$ was attained in 24 patients in group A and 20 patients in group B.

Conclusion: Moxonidine is slightly better as an antihypertensive than Telmisartan. At the same time, telmisartan has additional favourable effects on lipid profile (total cholesterol, LDL-C)

Key words: BP goals, Hypertension, Insulin resistance, Moxonidine and Telmisartan.
\end{abstract}

\section{INTRODUCTION:}

Hypertension is a major cause of cardiovascular diseases worldwide and hence responsible for increased morbidity and mortality. ${ }^{1}$ The overactivation of Renin Angiotensin System (RAS) results in increased synthesis of Angiotensin II which has vasopressor action and is strongly involved in the pathogenesis of hypertension. Along with hypertension insulin resistance is another important component of metabolic syndrome $^{2}$ and both of these are two independent predisposing risk factors for diabetes and also a strong association exists between these two. ${ }^{3}$ As per JNC VII guidelines goal to treat the hypertensive patients has been set to minimize the risk in such patients who develop serious cardiovascular complications. These goals can be achieved by proper treatment with antihypertensive drugs and improving the life style of the patients. ${ }^{4}$ A number of drugs like centrally acting agents, angiotensin receptor blockers ${ }^{5,6}$, angiotensin (c) 2011-15, JDDT. All Rights Reserved converting enzyme inhibitors, calcium channel blockers, diuretics and $\beta$ blockers etc. are used to treat this disorder. Out of all these anti-hypertensives, $\beta$ blockers and diuretics (Thiazide and loop diuretics) can cause hyperglycemia and impairment of lipid profile ${ }^{7}$.

Moxonidine being an selective imidazoline receptor agonist, stimulates the imidazoline type 1 receptors in cardiovascular regulatory centres of the medulla and inhibits central sympathetic activity that leads to decrease in blood pressure. It also improves insulin sensitivity in patients of metabolic syndrome. ${ }^{8}$ Recent in vitro data indicates that Telmisartan activates peroxisome proliferator-activated receptor c (PPAR-c) and increase adiponectin protein content in adipocytes. By this means, it may improve insulin sensitivity in vivo. ${ }^{9}$ 
According to the various studies conducted in various countries, angiotensin receptor blockers ${ }^{10}$ and centrally acting agents have been found to have a better safety profile than other antihypertensives. Few studies have been made in India and this study has been made keeping in view the people of North India especially the Punjabis of Majha-region because their socio-economic background and standard of living is quite different from the people of Western countries.

The present study is meant to see the effects of the Moxonidine (newer antihypertensive) and Telmisartan as monotherapy on insulin resistance and blood pressure and goals achieved according to JNC VII guidelines.

\section{METHODOLOGY:}

This was a randomized, open-label, parallel study, conducted to assess the effects of Moxonidine $(0.3 \mathrm{mg})$ and Telmisartan (40 mg) as monotherapy daily for 12 weeks. 60 patients (30 in each group) of hypertension, aged $>18$ years of either sex, were selected visiting the
OPD of Department of Medicine, Govt. Medical College, Amritsar. This study has already been approved by the Institutional Ethical Committee. Patient's written consent was taken before the commencement of the study. Both the study drugs have been allocated among the patients randomly. Patients were evaluated at day 0 and then at 12 weeks for clinical examination, lipid profile, insulin resistance and other parameters while blood pressure was recorded on every visit i.e. biweekly.

Inclusion: Patients of either sex with Age>18 years, hypertensive patients as diagnosed according to JNC 7 guidelines and with fasting blood sugar $\leq 125 \mathrm{mg} / \mathrm{dl}$ were eligible for participation in the study and patients with age $<18$ years, those having diabetes mellitus, secondary hypertension, severe cardiovascular disorders, those taking steroid or hormonal therapy, hepatic, renal and thyroid disorders and pregnant women were excluded from the study.

\section{Flowchart:}

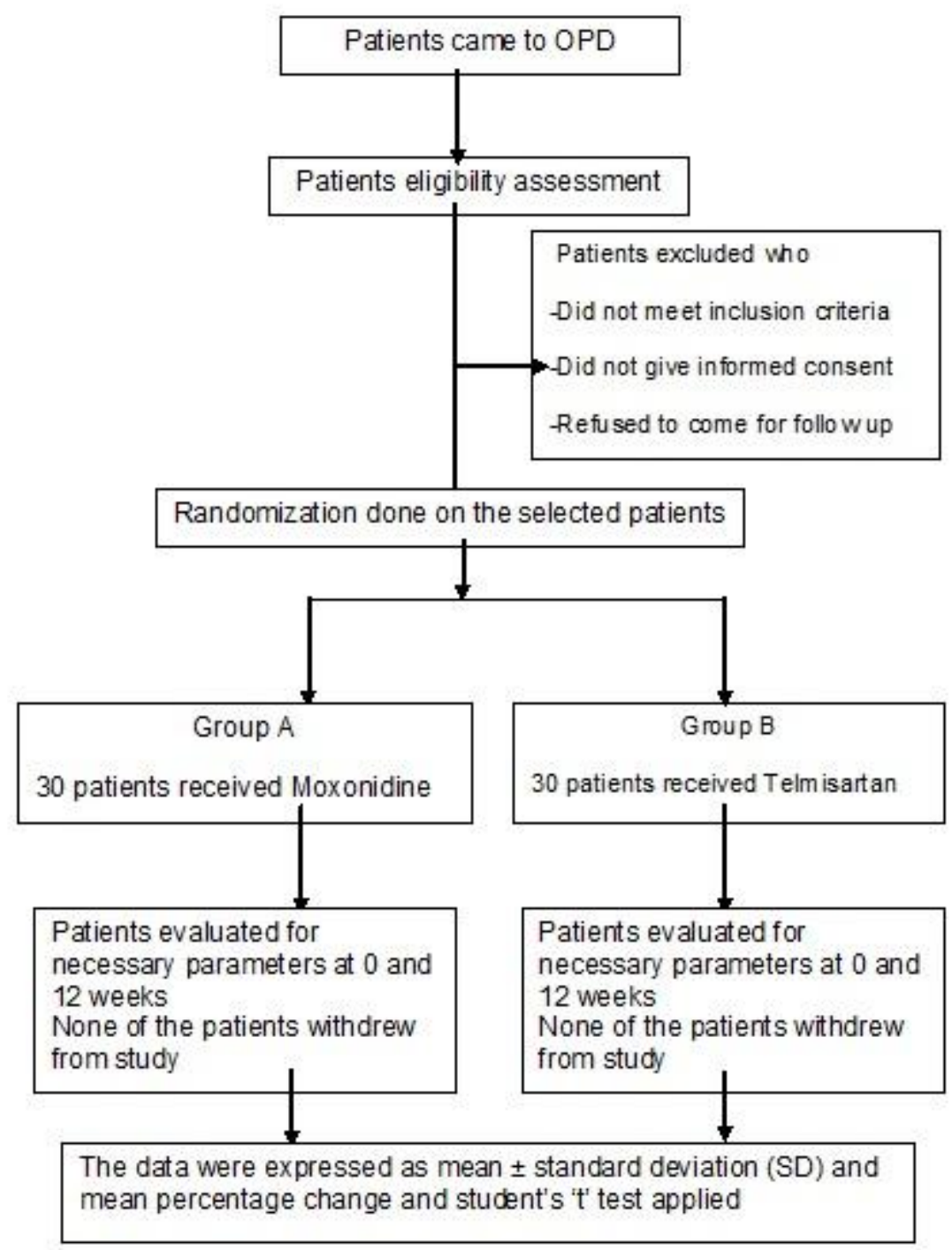


Statistical Analyses: The data were expressed as mean \pm standard deviation (SD) and mean percentage change. Treatment effects were tested with a paired student's ' $t$ ' test.

\section{RESULTS:}

Baseline characteristics (Table I) and baseline levels of different parameters (Table II) of the group A and group B were compared at the start of therapy. The difference in both the groups was statistically insignificant $(\mathrm{p}>0.05)$ at baseline (0 day).

Monotherapy of Moxonidine and Telmisartan in group A and group B showed significant fall in systolic and diastolic blood pressures at 12 weeks(Table III). Both the drugs also showed significant fall in levels of fasting blood glucose, fasting plasma insulin and HOMA-IR.
In group A, patients had more fall in levels of FBG and FPI as compared to fall in group B patients while levels of HOMA-IR showed equivalent fall in both the groups(Table III).Patients of group A showed a significant fall in TGs level and patients of group B showed a significant fall in levels of TC and LDL-C.

BP goal to achieve SBP $<140 \mathrm{~mm} \mathrm{Hg}$ and DBP $<90$ was attained in 24 patients $(80 \%)$ in group $A$ and 20 patients( $(67 \%)$ in group B.

Side effects: In group A (Moxonidine), Sedation in $13 \%$ (4) patients, dryness of mouth in $10 \%$ (3) patients and headache in $6 \%$ (2) patients was observed, while, in group B (Telmisartan), dry cough in $13 \%$ (4) patients was observed. None of the serious adverse events observed in both the treatment groups.

TABLE-I

\begin{tabular}{|c|c|c|c|}
\hline \multicolumn{2}{|c|}{ Baseline Characteristics } & Group- A & Group- B \\
\hline \multicolumn{2}{|c|}{ Age (yrs) } & $57.4 \pm 10$ & $54.06 \pm 9.1$ \\
\hline \multicolumn{2}{|c|}{ Sex (Male:Female) } & $13: 17$ & $15: 15$ \\
\hline \multirow{2}{*}{ Hypertension } & Newly diagnosed & 13 & 12 \\
\cline { 2 - 4 } & Previously diagnosed & 17 & 18 \\
\hline \multirow{2}{*}{$\begin{array}{c}\text { Family history of } \\
\text { Hypertension }\end{array}$} & Positive & 15 & 16 \\
\cline { 2 - 4 } & Negative & 7 & 8 \\
\cline { 2 - 4 } & Unknown & 8 & 7 \\
\hline \multirow{2}{*}{$\begin{array}{l}\text { Family history of } \\
\text { Diabetes }\end{array}$} & Positive & 8 & 18 \\
\cline { 2 - 4 } & Negative & 16 & 5 \\
\cline { 2 - 4 } & Unknown & 6 & \\
\hline
\end{tabular}

TABLE- II

\begin{tabular}{|c|c|c|c|c|}
\hline \multicolumn{5}{|c|}{ Baseline Parameters Values } \\
\hline \multicolumn{2}{|l|}{ Parameters } & Group-A & Group-B & p-values \\
\hline \multirow[t]{2}{*}{ Blood Pressure (mm Hg) } & SBP & $148 \pm 13$ & $147 \pm 7$ & $\mathrm{p}>0.05$ \\
\hline & DBP & $90 \pm 9$ & $90 \pm 8$ & $p>0.05$ \\
\hline \multicolumn{2}{|c|}{ Heart Rate(per minute) } & $86 \pm 5$ & $85 \pm 4$ & $p>0.05$ \\
\hline \multicolumn{2}{|c|}{ BMI $(\mathrm{kg} / \mathrm{m} 2)$} & $27 \pm 4$ & $26 \pm 3$ & $p>0.05$ \\
\hline \multicolumn{2}{|c|}{ Hip Circumference $(\mathrm{cm})$} & $98 \pm 9$ & $97 \pm 6$ & $p>0.05$ \\
\hline \multicolumn{2}{|c|}{ FBG $(\mathrm{mg} / \mathrm{dl})$} & $103 \pm 11$ & $105 \pm 13$ & $p>0.05$ \\
\hline \multicolumn{2}{|l|}{ FPI $(\mu \mathrm{U} / \mathrm{ml})$} & $10 \pm 1$ & $10 \pm 1$ & $p>0.05$ \\
\hline \multicolumn{2}{|l|}{ HOMA-IR } & $2 \pm 0.4$ & $3 \pm 0.4$ & $p>0.05$ \\
\hline \multicolumn{2}{|c|}{ TC (mg/dl) } & $214 \pm 21$ & $218 \pm 25$ & $p>0.05$ \\
\hline \multicolumn{2}{|c|}{ HDL-C (mg/dl) } & $44 \pm 5$ & $47 \pm 7$ & $p>0.05$ \\
\hline \multirow{2}{*}{\multicolumn{2}{|c|}{$\begin{array}{c}\text { LDL-C (mg/dl) } \\
\text { TG (mg/dl) }\end{array}$}} & $133 \pm 20$ & $137 \pm 23$ & $p>0.05$ \\
\hline & & $168 \pm 30$ & $172 \pm 19$ & $p>0.05$ \\
\hline \multicolumn{2}{|l|}{ TG (mg/dl) } & e in mean $=$ & & \\
\hline
\end{tabular}


TABLE-III

\begin{tabular}{|c|c|c|}
\hline & \multicolumn{2}{|c|}{ Mean percentage change in the parameters at 12 weeks } \\
\hline Parameters & Moxonidine Group & Telmisartan Group \\
\hline SBP & $\mathbf{1 2}$ weeks & 12 weeks \\
\hline DBP & $-9.5 \%(\mathrm{p}<0.0001)$ & $-7.4(\mathrm{p}<0.0001)$ \\
\hline FBG (mg/dl) & $-8.9(\mathrm{p}<0.0001)$ & $-5.6(\mathrm{p}=0.002)$ \\
\hline FPI( $\boldsymbol{\mu U} / \mathbf{m l})$ & $-5(\mathrm{p}<0.05)$ & $-5(\mathrm{p}<0.0008)$ \\
\hline HOMA-IR & $-11.5(\mathrm{p}<0.0001)$ & $-7.2(\mathrm{p}<0.002)$ \\
\hline TC $(\mathbf{m g} / \mathbf{d l})$ & $-7.0(\mathrm{p}<0.05)$ & $-8(\mathrm{p}<0.0001)$ \\
\hline HDL-C $(\mathbf{m g} / \mathbf{d l})$ & $-3(\mathrm{p}=0.2)$ & $-5(\mathrm{p}=0.1)$ \\
\hline LDL-C $(\mathbf{m g} / \mathbf{d l})$ & $+1.8(\mathrm{p}=0.6)$ & $-10(\mathrm{p}<0.0001)$ \\
\hline TG $(\mathbf{m g} / \mathbf{d l})$ & $+0.8(\mathrm{p}=0.6)$ & $-3(\mathrm{p}=0.1)$ \\
\hline
\end{tabular}

\section{DISCUSSION:}

\section{Group A}

Moxonidine $0.3 \mathrm{mg}$ per day in group A resulted in statistically significant fall in levels of SBP and DBP at 12 weeks (Table III). Fall in both these parameters was slightly more as reported by Sanjuliani et $\mathrm{al}^{11}$ at the end of 12 weeks. BP goal to achieve SBP $<140 \mathrm{~mm} \mathrm{Hg}$ and DBP $<90$ was attained in 24 patients $(80 \%)$ in group A.

Again, a fall of $11.5 \%$ in levels of fasting plasma insulin was observed in group 'A' while Sanjuliani et $\mathrm{al}^{11}$ reported a fall of $19 \%$. FBG level falls by $4.4 \%$ at the end of 12 weeks which are slightly more $(5.76 \%)$ as stated by Jose Abellan et al. ${ }^{12}$ While HOMA-IR value drops by $7.0 \%$ in present study, a fall of $13 \%$ was observed by Sanjuliani et $\mathrm{al}^{11}$ (Table III).

A significant reduction of $12.5 \%$ in TG levels was observed after a treatment of 12 weeks(Table III) and Sanjuliani et $\mathrm{al}^{11}$ stated a reduction of $10.3 \%$ in the levels of TG.

\section{Group B}

Telmisartan $40 \mathrm{mg}$ per day in group B resulted in statistically significant fall in levels of SBP and DBP at 12 weeks (Table III). With Telmisartan, a mean fall of
$11 \mathrm{mmHg}$ in SBP and $5 \mathrm{mmHg}$ in DBP was observed in present study while a mean fall of $16 \mathrm{mmHg}$ in SBP and $6 \mathrm{mmHg}$ in DBP was reported by An Doc Jung et al. ${ }^{13}$ Telmisartan successfully achieved BP goal of SBP <140 $\mathrm{mm} \mathrm{Hg}$ and DBP $<90$ in 20 patients $(\sim 67 \%)$ in group B.

FBG level fall by $3.7 \%$ (Table III) and Nagel JM et $\mathrm{al}^{14}$ reported a fall by $3.8 \%$. In FPI levels after 12 weeks of treatment a significant reduction of $0.4 \mu \mathrm{U} / \mathrm{ml}$ $(5 \%)$ (Table III) was observed while Nagel JM et $\mathrm{al}^{14}$ declared a mean fall of $2.3 \mu \mathrm{U} / \mathrm{ml}$.

Fall in HOMA-IR value was $7.2 \%$ (Table III) Whereas, this fall was more as stated by Nagel JM et al ${ }^{14}(16 \%)$.

Telmisartan significantly reduced TC levels by $8 \%$ and LDL-C levels by $10 \%$ (Table III) and a reduction by $8.95 \%$ in the levels of TC and $11.5 \%$ in levels of LDL$\mathrm{C}$ after 12 weeks of treatment was declared by Nagel JM et al. ${ }^{14}$

Comparison of Moxonidine vs Telmisartan:- On comparing moxonidine and telmisartan it was found that moxonidine was better antihypertensive than telmisartan. Moxonidine also resulted in achievement of goal for blood pressure in more number of patients as compared to telmisartan. (Table IV)

TABLE IV: Blood Pressure control with Moxonidine versus Telmisartan

\begin{tabular}{|c|c|c|}
\hline \multirow{2}{*}{ Test values } & \multicolumn{2}{|c|}{ BP control with Drug Group A vs B } \\
\cline { 2 - 3 } & SBP & DBP \\
\hline p-value & $\mathrm{p}=0.02$ & $\mathrm{p}=0.001$ \\
\hline
\end{tabular}

It has been seen that both the drugs were equivalent in improving the parameters of insulin resistance. But their effects were variable on the different parameters of lipid profile. Telmisartan was found to be more effective in reducing $\mathrm{TC}$ and LDL-C than moxonidine, whereas, moxonidine was more effective in reducing TG levels than telmisartan.

Clinical assessment and blood tests of the patients had not shown any serious adverse events during the trial, indicated that these drugs were well tolerated by those (c) 2011-15, JDDT. All Rights Reserved patients and none of the patients were withdrawn during it. Mild side effects were seen like sedation in $13 \%$ (4) patients, dryness of mouth in $10 \%$ (3) patients and headache in $6 \%$ patients in group A (Moxonidine) and dry cough in $13 \%$ (4) patients in group B (Telmisartan).

There is a need to confirm the result on the basis of larger trial so that we could better treat the hypertensive patients according to India's socio-cultural scenario. 


\section{CONCLUSION:}

Moxonidine was found to be slightly better antihypertensive than telmisartan as the desired goal of blood pressure was achieved in more number of patients

\section{REFERENCES}

1. Ezzati M, Lopez AD, Rodgers A, Vander Hoorn S, Murray CJ. Selected major risk factors and global and regional burden of disease. Lancet 2002;360:1347-60.

2. Beale EG. Insulin Signaling and Insulin Resistance. J Investig Med 2013 Jan;61(1):11-4.

3. Dyer AR, Liu K, Walsh M, Kiefe C, Jacobs DR Jr, Bild DE Ten-year incidence of elevated blood pressure and its predictors: the CARDIA study. J Hum Hypertens 1999;13:13-21.

4. Chobanian AV, Bakris GL, Black HR, Cushman WC, Green LA, Izzo JL et al. The Seventh Report of the Joint National Committee on Prevention, Detection, Evaluation, and Treatment of High Blood Pressure: the JNC 7 report. JAMA 2003;289(19):2560-72.

5. Fierens F, Vanderheyden PM, De Backer JP, Vauquelin G. Binding of the antagonist $[3 \mathrm{H}]$ candesartan to angiotensin II AT1 receptor-transfected [correction of tranfected] Chinese hamster ovary cells. Eur J Pharmacol 1999;367(2-3):413-22.

6. Fierens FL, Vanderheyden PM, De Backer JP, Vauquelin G. Insurmountable angiotensin AT1 receptor antagonists: the role of tight antagonist binding. Eur $\mathrm{J}$ Pharmacol 1999;372(2):199-206

7. Papadakis JA, Mikhailidis DP, Vrentzos GE, Kalikaki A, Kazakou I, Ganotakis ES. Effect of antihypertensive treatment on plasma fibrinogen and serum HDL levels in patients with essential hypertension. Clin Appl Thromb Hemost 2005;11(2):139-46. with moxonidine therapy. Both the drugs were equivalent in improvement of insulin resistance.

Competing interests: None

8. Haenni A, Lithell H. Moxonidine improves insulin sensitivity in insulin-resistant hypertensives. J Hypertens Suppl 1999;17(3):S29-35.

9. Benson SC, Pershadsingh HA, Ho CI, Chittiboyina A, Desai $\mathrm{P}$, Pravenec $\mathrm{M}$ et al. Identification of telmisartan as a unique angiotensin II receptor antagonist with selective PPAR gamma-modulating activity. Hypertension 2004;43(5):9931002 .

10. Domenico Galzerano, Cristina Capogrosso, Sara Di Michele, Antonio Galzerano, Paola Paparello, Diana Lama et al. New standards in hypertension and cardiovascular risk management: focus on telmisartan. Vascular health and risk management 2010;6

11. Sanjuliani AF, Abreu VG, Francischetti EA. Selective imidazoline agonist moxonidine in obese hypertensive patients. Int J Clin Prac 2006;60(5):621-5.

12. Abellan J, Mariano L, Fernando HM. Efficacy of moxonidine in the treatment of hypertension in obese noncontrolled hypertensive patients. Kidney International 2005;67(93):S20-4.

13. An Doc Jung, MD, Weon Kim, MD, Sang Hyun Park, MD, Jeong Su Park, MD, Sang Cheol Cho, MD, Sung Bum Hong, MD et al. The Effect of Telmisartan on Endothelial Function and Arterial Stiffness in Patients With Essential Hypertension. Korean Circ J 2009;39:180-4.

14. Nagel JM, Tietz AB, Goke B, Parhofer KG. The effect of telmisartan on glucose and lipid metabolism in nondiabetic, insulin-resistant subjects. Metabolism 2006 Sep;55(9):114954. 